\title{
How to Effectively Design Referral Rewards to Increase the Referral Likelihood for Green Products
}

\author{
Di Kuang ${ }^{1, * \mathbb{D}}$, Xiao-Fei Li ${ }^{2,3}$ and Wen-Wen Bi ${ }^{4}$ \\ 1 School of Management and Economics, Beijing Institute of Technology, Beijing 100081, China \\ 2 College of Business Administration, Capital University of Economics and Business, Beijing 100070, China; \\ lixf6@sem.tsinghua.edu.cn \\ 3 School of Economics and Management, Tsinghua University, Beijing 100084, China \\ 4 School of Economics and Management, Yan'an University, Yan'an 716000, China; sdauwenwen@163.com \\ * Correspondence: dkuang_33@163.com; Tel.: +86-10-68915602
}

Citation: Kuang, D.; Li, X.-F.; Bi, W.-W. How to Effectively Design Referral Rewards to Increase the Referral Likelihood for Green Products. Sustainability 2021, 13, 7177. https://doi.org/10.3390/su13137177

Academic Editor: Antonino Galati

Received: 27 May 2021

Accepted: 22 June 2021

Published: 25 June 2021

Publisher's Note: MDPI stays neutral with regard to jurisdictional claims in published maps and institutional affiliations.

Copyright: (c) 2021 by the authors. Licensee MDPI, Basel, Switzerland. This article is an open access article distributed under the terms and conditions of the Creative Commons Attribution (CC BY) license (https:// creativecommons.org/licenses/by/ $4.0 /)$.

\begin{abstract}
Interpersonal referrals can effectively promote purchases. In view of the low sales of green products, this study introduces the referral reward program into green marketing and investigates the impact of reward type on customers' referral likelihood for green product. Through a lab experiment with 302 participants in China involved, this study reveals the differential effects of monetary versus donation rewards on existing customers' referral likelihood. Specifically, compared with monetary rewards, donation rewards are more effective in promoting recommendations. It is also indicated that the perceived fit between the reward and green products partially mediates the relationship between the reward type and referral likelihood. In addition, the relationship between the reward type and perceived fit is moderated by consumers' green product knowledge. This research not only extends the literature on green marketing and referral reward programs, but also provides feasible suggestions for government and enterprises to promote green products and to improve social wellbeing.
\end{abstract}

Keywords: green product; referral reward program; reward type; perceived fit; referral likelihood

\section{Introduction}

The increasingly serious environmental problems highlight the importance of sustainable development. In this case, more and more companies have begun to implement environmentally friendly strategies and produce green products [1,2]. However, barely do their actions receive an equally considerable response from customers. Only a few people are willing to buy green products, which leads to very low sales of green products [3]. This is largely due to customers' insufficient understanding of green products and concerns about product quality and environmental functions [4]. Research shows that interpersonal recommendation can effectively reduce customers' perceived risk and increase their willingness to buy [5]. Therefore, companies should adopt effective methods to encourage existing customers to recommend products to potential customers, which would help to prompt potential customers' purchase [6]. In the field of non-green products, numerous companies have achieved good returns by designing and implementing referral reward programs. Referral reward programs (RRPs hereinafter) refer to a marketing method that encourages existing customers to refer potential customers by providing rewards to existing customers [7-9]. However, in the field of green products, it is still unclear how to design and implement the RRPs to effectively increase the referral likelihood of existing customers.

The reward type is a key component of RRPs [10]. Among them, monetary rewards and donation rewards are two types of rewards with opposite attributes. Specifically, the self-interested attributes of monetary rewards are strong [11], while donation rewards, which refers to enterprises donating to charities in the name of referrers, have more 
altruistic attributes (prosocial attributes). In the field of marketing for ordinary products, monetary rewards are far more widely adopted than donation rewards. Many managers and researchers even default the type of reward to monetary rewards. This is mainly because monetary rewards have higher economic value than donation rewards, which help to increase the attractiveness of monetary rewards to existing customers [11]. However, in the field of green product marketing, little is known about what type of referral rewards should be implemented. It should be noted that green products have strong pro-social attributes, making them different from ordinary products [12]. In this case, for green products, which kind of reward type (monetary rewards or donation rewards) is more effective might depend on the matching degree of the characteristics between the reward and the green product. Therefore, this study adopts the perceived fit as the mediation variable and suggests that it can effectively explain the internal mechanism of the effect of reward types on customers' referral likelihood for green products. The degree of perceived fit refers to the similarity or matching degree of attributes between objects [13-15]. Specific to the context of the RRPs for green product, the perceived fit refers to the similarity or matching degree of the attributes between the referral reward and the green product. In addition, customers' perception and understanding of things depends on their level of knowledge [16]. In this case, it can be inferred that when customers have different levels of knowledge about green products, their perceptions of the fit between the reward and the green product may also be different. Thus, green product knowledge is introduced as a moderating variable in this research.

This study focuses on green products, aiming to explore how reward type influences existing customers' referral likelihood for green products. Specifically, this study examines the differential impact of monetary versus donation rewards on the referral likelihood and explores the mediating role of the perceived fit in this process. Besides, the moderating effect of green product knowledge on the relationship between reward types and the perceived fit is also discussed. On one hand, this study contributes to the literature by paying attention to the referral behavior and introducing the RRPs into the research of green marketing; on the other hand, the impact of perceived fit between the reward and green products is investigated in the context of RRPs, which contributes to an extensive understanding of the impact of the perceived fit. Managerially, the conclusion of this research can not only help enterprises to promote and publicize green products effectively, but also provide some feasible suggestions for governments, enterprises and schools to improve social well-being (such as increase customers' knowledge of green products through publicity and training).

The rest of this paper is structured as follows. Section 2 presents the theoretical background. In Section 3, we develop the hypotheses of the current research. In Section 4, the research method is shown. Section 5 provides the empirical analysis and the results of data analysis. In Section 6, we conclude the paper with a discussion of the research conclusions and implications.

\section{Theoretical Background}

\subsection{Green Products and Green Marketing}

Green products mainly refer to the products, in the whole process of which life cycle, that meet specific environmental protection requirements, are harmless to human health, harmless or minimal to the ecological environment, and of high resource utilization, low energy consumption, and conducive to resource regeneration and recycling products $[17,18]$. According to its definition, green product has strong pro-environmental and pro-social attributes. In our daily practice, common green products include products made from recycled or biodegradable materials and energy-saving appliances [19].

Existing research in the green marketing field can be divided into three categories. The first category mainly explores the demographic characteristics of customers who are willing to buy green products, such as gender, income, education, etc. Specifically, studies have confirmed that women are more likely to choose and purchase green products than 
men [20]. Groups with higher education and income are more willing to pay extra for green products $[21,22]$. In addition, the more children there are in the family, the more green products the family purchase despite their decreasing willingness to pay extra for the green products $[22,23]$. The second category is to identify the psychological factors that affect consumers' green buying behavior based on the consumer's psychological decision-making process. Consumers' environmental psychological factors (such as environmental values, environmental care and environmental responsibility) and moral psychological factors (e.g., social norms, social identity and moral identity) are the most important psychological factors that drive consumers' green buying behavior [24-26]. The third category is based on the external context factors such as products, prices, advertisements, and policies, analyzing the green purchase obstacles caused by the premium of green products or investigating the effects of the traditional marketing activities and policies on green purchase behavior.

To sum up, existing research on green marketing mainly focuses on the green purchase behavior itself and pays little attention to the recommendation behavior of green products. However, it should not be ignored that the unideal sales of green products are largely due to customers' insufficient understanding of green products and concerns about the product quality. Although companies have invested a lot in traditional marketing activities such as advertising and public relations to promote green products, the increasing greenwashing and the declining advertising credibility have caused a losing trust of customers in marketing activities dominated by enterprises $[27,28]$. Thus, companies need to find a way that customers trust to introduce and promote green products. Interpersonal recommendation based on daily social connection, which has won trust from customers, is an effective way to increase customers' understanding of products and to reduce their perceived risk and uncertainty. Therefore, making good use of interpersonal recommendations and exploring ways to enhance the possibility of customer recommendations can help companies to improve potential consumer trust and purchase intention.

\subsection{RRPs and Reward Types}

As an effective marketing tool to stimulate the referral, the RRPs have received great attention and been adopted in the marketing practices of ordinary products. Rewards are included in the program to promote existing customers to recommend products to potential customers, thereby realizing the transformation of interpersonal social capital into economic capital [10]. What's more, the RRPs have been proven not only to help attract potential customers, but also to maintain existing customers and increase their loyalty $[29,30]$. However, the existing research on RRPs mainly focuses on ordinary products, leaving its effects on green products unclear.

The key to implementing RRPs is the design of the referral reward. A proper reward type may increase the referral likelihood to a greater extent [31]. As stated, monetary rewards and donation rewards are two quite different reward types. The main difference between the two kinds of rewards lies in their attributes and the benefits they bring. Specifically, monetary rewards have stronger self-interest attributes and bring economic benefits to referrers $[10,11]$. As a contrast, donation rewards involve little personal financial gain, instead, they generate psychological or social benefits [10]. In addition, donation rewards show more care for the society, leading their typical features lie in their strong pro-social attributes $[10,32]$.

In the field of ordinary products, monetary rewards have been seen equally or more effective in motivating customer referrals than the other types of rewards, because they show higher economic value and greater freedom of use for recommenders, therefore, many studies default the reward type to monetary rewards, such as Song et al. [33], Yu et al. [34], and Wirtz and Chew [35] etc. However, green products, which have strong pro-social and pro-environmental attributes, are significantly different from ordinary products. Moreover, the design of the reward types should depend on the characteristics of the product [31]. In this case, it is necessary to further explore whether monetary rewards are more helpful to improve existing customers' referral likelihood for green products, and at the same 
time, how did it happen and under what conditions the effect of reward type will be strengthened should also be investigated.

\section{Hypotheses Development}

\subsection{The Effect of the Reward Type on Referral Likelihood}

As mentioned above, monetary rewards have strong self-interest attributes, while donation rewards have strong pro-social attributes. And the perceived fit reflects the similarity or matching degree of the attributes between the referral reward and the green product. In this case, it can be inferred that there is a higher perceived fit between donation rewards and green products. Some research areas in marketing, such as brand expansion, sponsorship and celebrity endorsement have analyzed the impact of the fit. However, there are very few studies on the fit in the context of the RRP, especially the RRP for green products.

Specifically, a large number of empirical studies on brand extension have emphasized the importance of the perceived fit between the parent brand and its extended brand [36,37]. Volckner and Sattler [38] found that the fit between the parent brand and its extended brand is the most significant driving force for successful brand extension. In addition, researchers in the field of brand alliances also supported the concept of fit. Simonin and Ruth [39] demonstrated that the high degree of fit between two brands in a brand alliance would enhance customers' attitudes towards the alliance. If the customer's perceived fit is high, the customer is more likely to experience a high cognitive consistency, which can prompt them to respond positively $[37,40,41]$. Furthermore, in the related research on sponsorship and celebrity endorsements, Mazodier and Merunka [42] uncovered that the perceived fit between the sponsored event and the brand would have a positive impact on brand trust. Similarly, the celebrity advertising programs would be more effective when there is a close fit between celebrities and endorsement products [43-45]. In addition, literature on olfactory cues [46] has also reached a similar conclusion that environmental odors that are consistent with the retail environment (for example, the plant aroma in a flower shop) can cast a positive impact on consumer's selection process. By contrast, inconsistent odors would have a negative impact.

In the context of the RRPs for green products, this article elaborates on the effect of perceived fit based on relevant theory. Specifically, the effect of perceived fit can be explained by consistency theory [47], cognitive dissonance theory [48], and classification theory $[13,49]$. First, according to congruence theory [47] and cognitive dissonance theory [48], customers tend to pursue cognitive and emotional consistency. This means that when customers are faced with an RRP for green products, they will pay attention to the cognitive consistency between the association stimulated by the green product and the association of the reward [14]. Specifically, the higher customers' perceived fit between the green product and the reward, the more cognitive consistency of the stimulated associations and the more positive emotional experience the consumers may perceive, which makes it more possible for them to respond positively to the RRP. Second, the classification theory believes that people will classify certain objects or information to help them effectively process and understand the surrounding information [50]. If people regard an object as a member of a certain category, their emotions and beliefs about other objects in this category will be transferred to the object to a certain extent. Based on the classification theory $[13,49]$ and the definition of consumer's perceived fit [13-15], a conclusion can be drawn that when the perceived fit between the green product and the reward is high, customers are more inclined to classify the green product and the reward as the same category in their cognition system. In this case, they are more likely to transfer their existing positive attitude towards the green product to the reward, resulting in an increase in their preference for the reward and a higher referral likelihood. Therefore, this research proposes the following hypotheses: 
Hypothesis 1 (H1). Compared with monetary rewards, donation rewards are more helpful to increase customers' referral likelihood for green products.

Hypothesis 2 (H2). Customers' perceived fit mediates the effect of the reward type on their referral likelihood for green products.

\subsection{The Moderating Effect of the Green Product Knowledge}

As stated, the reward type affects customer's perceived fit between the reward and green products. Furthermore, this study infers that the relationship between reward types and perceived fit may also be affected by the knowledge about green products. Existing research reveals that knowledge is a key factor affecting people's interpretation and perception of information, their evaluation of preferences, and a series of behaviors [16]. Specific to the context of green products, it can be deduced that if customers are occupied with different levels of green product knowledge, they may show different perceptions and responses to similar stimulus (such as the referral reward designed for green products).

Accordingly, customers with a higher level of green product knowledge would pay more attention to the impact of products on the environment, and thus, they would be more willing to buy green products [51]. Since the purchase of green products is a kind of pro-social behavior [18], customers who are qualified with more green knowledge would have a higher pro-social tendency. Compared with monetary rewards, donation rewards, which have stronger pro-social attributes, show greater benefit to others and society. In this case, customers with a higher level of green product knowledge would recognize donation rewards more than those with a lower level of green product knowledge and perceive a higher fit between donation rewards and green products. Therefore, this research proposes the following hypothesis:

Hypothesis 3 (H3). The effect of the reward type on customers' perceived fit is moderated by their green product knowledge. Specifically, when customers have a higher level of green product knowledge, the effect of reward type on their perceived fit will be enhanced.

In order to better understand the impact of reward type on the referral likelihood and its mechanism, this paper draws a corresponding conceptual framework, as shown in Figure 1.

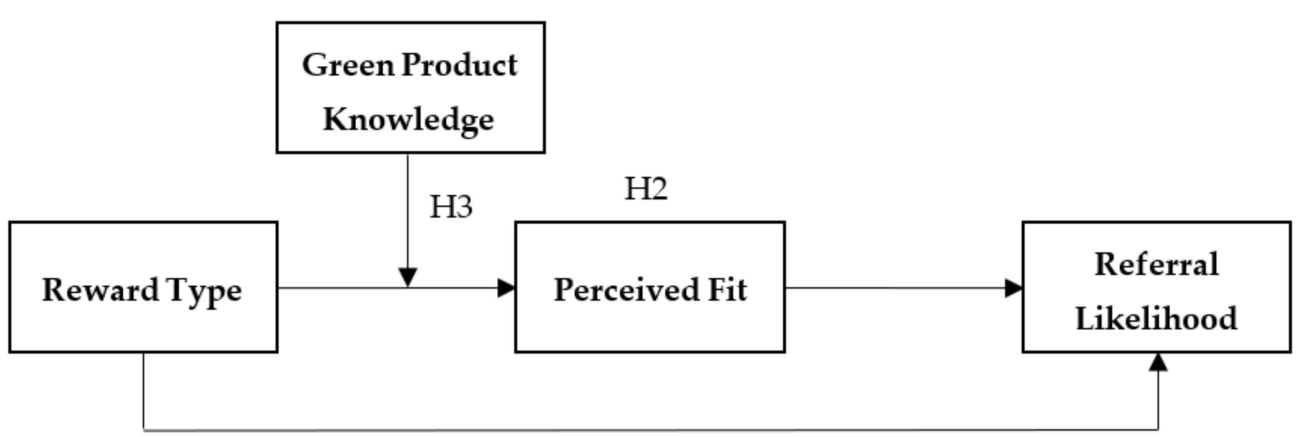

$\mathrm{H} 1$

Figure 1. Research model.

\section{Methods}

\subsection{Research Method}

In order to test the hypothesis, a 2 (reward type: monetary reward vs. donation reward) +1 control group (no RRP) between-subject experiment was conducted. The experiment was conducted through questionnaires on Sojump. Similar to MTurk, Sojump is a professional online survey platform in China and can provide access to data of a quality equivalent to traditional sampling approaches [52]. Respondents who completed the questionnaire were rewarded with Sojump points. 302 graduate students recruited 
in China participated in this experiment and were randomly assigned to one of the three groups: the monetary reward group, the donation reward group, or the no RRP group.

The reasons for using the experimental scenario approach for data collection are as follows. First, providing participants with a scenario rather than solely relying on their memory of similar past experiences minimizes memory bias, which is a common problem in surveys using self-reports [53]. Second, this experiment method could reduce the problems that in terms of the research context involve the impact of personal circumstances [54]. Third, the approach could lead to a reduction of random noise during data collection by providing the same scenario for all participants within one group. Finally, an experimental setting provides an access to control the manipulated variables, which helps to enhance the internal validity of the research results [55].

The applied scenarios involved the usage of a fictitious firm brand, which is called Lucky Trolley in this study, as it is commonly done by leading researchers in the wordof-mouth field $[10,30]$. By avoiding the usage of real brands, the authors sought to rule out the influence of prior brand beliefs [56]. To control for potential differences, this study incorporates product involvement as a control variable, which is consistent with existing research on RRPs $[10,57,58]$. Product involvement reflects customers' enduring perceptions of the importance of a product category, according to their inherent needs and interests [59]. The higher product involvement customers have, the more likely they are to express their emotions and convey word-of-mouth information to others [60].

\subsection{Experimental Materials}

The green product used in this experiment is an environmentally friendly backpack which has been adopted by prior research (i.e., Yu et al. [12]). And the backpack is common for our subjects (graduate student). Specifically, this study takes the eco-friendly backpack sold on Jingdong Mall as a prototype [61], and appropriately modifies its description to form the introduction to the backpack in this research. The introduction to the backpack can be divided into two parts. The first part provides general information such as the price and the capacity of the backpack. The second part introduces the environmental protection properties of the backpack, main content including that the backpack is made by 15 recycled water bottles as the main raw material, does not contain harmful substances and has less pollution to the environment in the production process. Once abandoned, it can be recycled again to maximize resource saving and reduce white pollution. To test whether the backpack used in this study has green attributes, we conducted a pretest through questionnaires on Sojump. 100 college students recruited online participated in this pretest and were asked to evaluate the following two items adapted from Yu et al. [12] on a 7-Likert type scale, namely, the backpack is a green product and people will think that the user of the backpack is compassionate. Result shows that the backpack does has green attributes $(\mathrm{M}=5.50>4, \mathrm{t}=17.589, p=0.000)$.

As for the information relevant to the RRP, the main content say that the Lucky Trolley flagship store sends you a text message and invites you to participate in the referral reward program. The procedure of joining this program is that you send a referral link to your friends or acquaintances, and once they purchase the backpack through the link and their receipt are confirmed, you will be rewarded accordingly. The description of the monetary reward scenario is "You will receive a cash reward of 30 yuan (\$4.61, equivalent to $15 \%$ of the backpack price)", while that of the donation reward scenario says "The store will donate 30 yuan ( $\$ 4.61$, equivalent to $15 \%$ of the backpack price) to Charity School on behalf of you".

\subsection{Experimental Procedure}

The experiment was conducted in four steps: To begin with, all subjects were asked to imagine that they had bought a backpack in the flagship store of Lucky Trolley Backpack. Then, they went through the introduction about the backpack and imagined that they had already used the backpack many times and felt very satisfied with it. In the second 
step, participants in the monetary reward group (donation reward group) were assigned to read the introduction to the RRP and the monetary reward situation (donation reward situation), while the control group was not asked to do so. Next, all participants reported their referral likelihood. In the third step, subjects in the monetary reward group and the donation reward group were asked to evaluate their perceived fit between the green products and the reward, green product knowledge, however, the control group was not required to evaluate these variables. Lastly, all participants answered their involvement in the backpack and their demographic information.

\subsection{Measurement of Variables}

The questionnaire included four variables: the perceived fit, green product knowledge, product involvement, and the referral likelihood. Mature scales from previous literature were used in this study. Among these variables, the perceived fit, green product knowledge, and product involvement are measured adopting the seven-point Likert type scale ( $1=$ strongly disagree, $7=$ strongly agree). The scale of perceived fit was adapted from Wang et al. [62]. The study employed the scale from Liobikien et al. [63] and Wang et al. [51] to measure green product knowledge. The scale of product involvement was adapted from Beatty and Talpade [64]. As for the referral likelihood, the scale was adapted from the study of Ryu and Feick [53] using a 100-point scale $(0 \%=$ certain not to recommend the backpack; $100 \%$ = certain to recommend the backpack).

Before the questionnaire was officially distributed, we conducted qualitative interviews and a pretest to check the understandability of the items. 30 graduate students from a university in Beijing, China participated in the interview and the pre-test. The reliability and validity of the questionnaire were tested. Further modifications were made to the questionnaire according to the feedback from the interviews and the pretest, which would help to make it easier for the respondents to understand the items. In addition, the measurement items are presented in Table 1.

Table 1. Constructs and measurement.

\begin{tabular}{|c|c|c|}
\hline Construct & Item & Factor Loading \\
\hline $\begin{array}{l}\text { Referral likelihood (adapted } \\
\text { from Ryu and Feick [53]) }\end{array}$ & $\begin{array}{l}\text { Please indicate your possibility of } \\
\text { recommending the backpack to others. }\end{array}$ & - \\
\hline \multirow{3}{*}{$\begin{array}{l}\text { Perceived fit (adapted from } \\
\text { Wang et al. [62]) }\end{array}$} & $\begin{array}{l}\text { The referral reward is suitable for } \\
\text { the backpack. }\end{array}$ & 0.878 \\
\hline & $\begin{array}{l}\text { The referral reward has a good } \\
\text { correlation with the backpack. }\end{array}$ & 0.789 \\
\hline & $\begin{array}{l}\text { For the backpack, the referral reward is } \\
\text { a logical choice. }\end{array}$ & 0.888 \\
\hline \multirow{2}{*}{$\begin{array}{l}\text { Green product knowledge } \\
\text { (adapted from Liobikien et al. } \\
\text { [63] and Wang et al. [51]) }\end{array}$} & $\begin{array}{l}\text { In general, I know about the } \\
\text { environmental impact of the products I } \\
\text { buy and use. }\end{array}$ & 0.704 \\
\hline & $\begin{array}{l}\text { I am agreed with that buying } \\
\text { environmentally friendly products can } \\
\text { make a real difference to the } \\
\text { environment. }\end{array}$ & 0.786 \\
\hline \multirow{4}{*}{$\begin{array}{c}\text { Product involvement } \\
\text { (adapted from Beatty and } \\
\text { Talpade [64]) }\end{array}$} & $\begin{array}{l}\text { In general, I am very interested in the } \\
\text { information about backpacks. }\end{array}$ & 0.738 \\
\hline & Backpacks are very important to me. & 0.899 \\
\hline & Backpacks matter a lot to me. & 0.866 \\
\hline & $\begin{array}{l}\text { I feel bored when other people talk to } \\
\text { me about backpacks. (Reversed code) }\end{array}$ & 0.742 \\
\hline
\end{tabular}




\section{Results}

In this research, SPSS 18 and AMOS 20 were employed to analyze the data. First, the reliability and validity of the measurement model were examined. Second, all hypotheses in this study were tested.

\subsection{Measurement Model}

To evaluate the psychometric adequacy of the constructs, we conducted confirmatory factor analysis. The factor loadings for each construct are shown in Table 1. The results illustrate that all factor loadings are significant $(p<0.001)$, ranging from 0.704 to 0.899 . In addition, the results of reliability, validity and correlations analysis of variables are shown in Table 2. Specifically, Cronbach's alphas for the main constructs are 0.713 or above, and composite reliability (CR) ranges from 0.715 to 0.889 (Table 2), both of which exceed the benchmark of 0.7, suggesting that all of these measures are reliable [65]. Convergent validity was assessed using the average variance extracted (AVE) from the constructs. All constructs range from 0.557 to $0.727 \mathrm{AVE}$, well above the recommended value of 0.50 . The AVE of each construct exceeds its squared correlation to any other construct, assuring the discriminant validity of the constructs.

Table 2. Reliability, validity and correlations analysis of variables.

\begin{tabular}{ccccccccc}
\hline Variable & $\alpha$ & AVE & CR & $\mathbf{1}$ & $\mathbf{2}$ & $\mathbf{3}$ & $\mathbf{4}$ & $\mathbf{5}$ \\
\hline 1-Reward Type & - & - & - & 1 & & & & \\
2-Referral Likelihood & - & - & - & $0.649 * *$ & 1 & & \\
3-Perceived Fit & 0.885 & 0.727 & 0.889 & $0.551^{* *}$ & $0.560^{* *}$ & 0.853 & \\
4-Green Product Knowledge & 0.713 & 0.557 & 0.715 & -0.084 & 0.130 & $0.285^{* *}$ & 0.746 & \\
5-Product Involvement & 0.883 & 0.663 & 0.887 & -0.011 & $0.197^{* *}$ & 0.080 & $0.196^{* *}$ & 0.814 \\
\hline
\end{tabular}

Note: $1 .{ }^{* *} p<0.01 ; 2$. The values on the diagonal are the square root of AVE.

\subsection{Main Effect}

Based on the independent sample $t$-test analysis, the referral likelihood in the monetary reward group is significantly greater than the control group (no RRP) (Mmonetary $=68.78$, Mno RRP $=66.21, \mathrm{t}(200)=2.374, p=0.019)$, and the referral likelihood in the donation reward group is significantly higher than the control group (no RRP) (Mdonation $=81.99$, Mno RRP $=66.21, t(199)=14.401, p=0.000$,). Further, as shown in Figure 2, the referral likelihood in the donation reward group is also significantly greater than the monetary reward group $($ Mdonation $=81.99$, Mmonetary $=68.78, \mathrm{t}(199)=12.036, p=0.000$ ). Thus, $\mathrm{H} 1$ is supported. Based on the analysis, we can find that compared with no RRP, both monetary rewards and donation rewards can improve customers' referral likelihood for green products. What's more, donation rewards will bring better results than monetary rewards.

\subsection{Mediation Effect}

According to the steps recommended by Baron and Kenny (1986), we verified the mediation effect in four steps: (1) testing the effect of independent variable on dependent variable; (2) examining the effect of independent variable on mediating variable; (3) testing the effect of the mediating variable on dependent variable; (4) Based on the first step, the mediating variable is added to predict dependent variable. If the effects of the first three steps are significant, the effect of mediating variable is significant and the effect of independent variable is not established in the fourth step, it can be speculated that the mediating variable plays a full mediating role; while if both the independent variable and mediating variable are significantly correlated with dependent variable, it can be judged that the mediating variable plays a partial mediating role.

Following the mediation test steps above, we examined the mediating effect of the perceived fit. As Table 3 shows, Model 2 reported the main effect that reward type is positively correlated with customers' referral likelihood for green products ( $\beta=1.299$, 
$p=0.000$ ). Model 3 illustrated the regression equation of reward type on the perceived fit, and the result indicated that rewards type is a positive correlation with the perceived fit $(\beta=1.098, p=0.000)$. Model 4 showed the regression equation of perceived fit on referral likelihood, and the result reported that perceived fit is positively related to referral likelihood ( $\beta=0.552, p=0.000$ ). On the basis of Model 2 , we added the mediating variable of perceived fit into the regression equation in Model 5 and the result reported that reward type is still positively related to referral likelihood $(\beta=1.001, p=0.000)$, and perceived fit is positively related to referral likelihood $(\beta=0.272, p=0.000)$, which reveals that the perceived fit plays a partial mediation role. Therefore, $\mathrm{H} 2$ is supported.

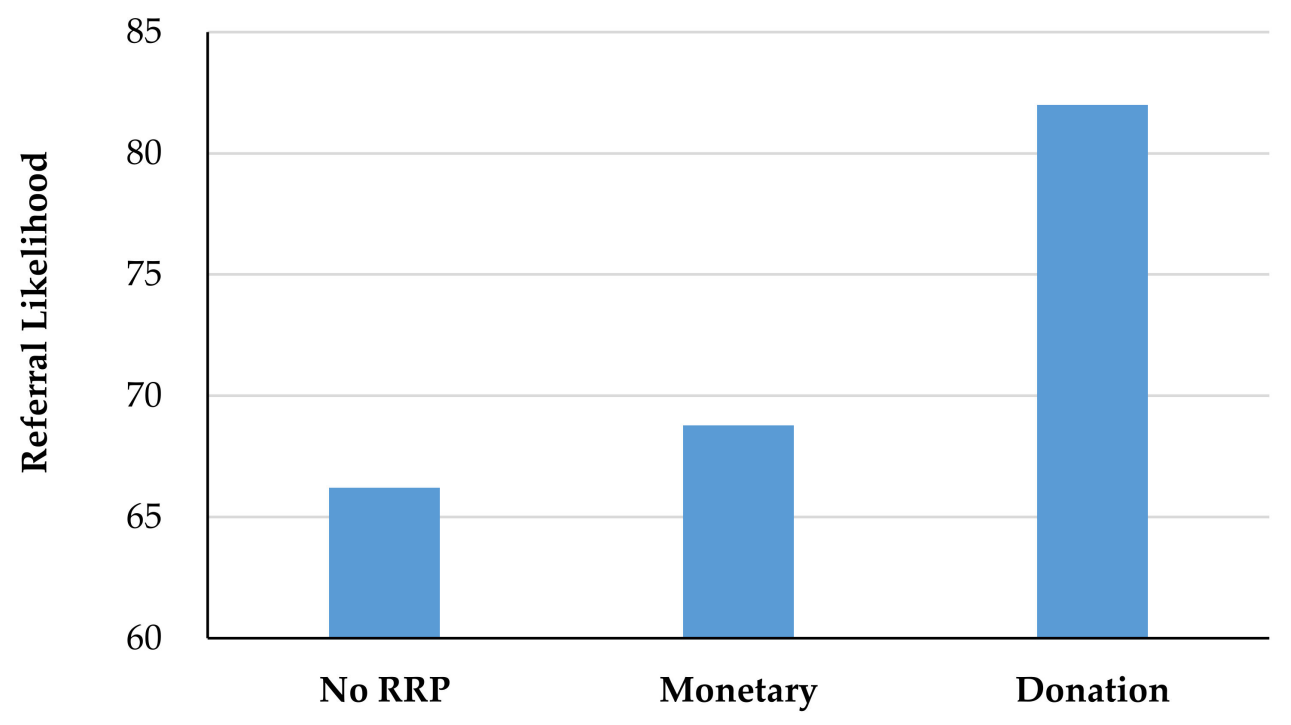

Figure 2. Customers' referral likelihood in different groups.

Table 3. Hierarchical regression results.

\begin{tabular}{lccccc}
\hline \multirow{2}{*}{$\begin{array}{c}\text { Dependent } \\
\text { Variables }\end{array}$} & \multicolumn{2}{c}{ Referral Likelihood } & $\begin{array}{c}\text { Perceived } \\
\text { Fit }\end{array}$ & \multicolumn{2}{c}{ Referral Likelihood } \\
\cline { 2 - 6 } & M1 & M2 & M3 & M4 & M5 \\
\hline Constant & -0.036 & $-1.941^{* * *}$ & $-1.944^{* * *}$ & 0.148 & $-1.413^{* * *}$ \\
Gender & 0.023 & -0.003 & 0.189 & -0.093 & -0.054 \\
Product & & $0.203^{* * *}$ & 0.064 & $0.163^{* *}$ & $0.186^{* * *}$ \\
Involvement & $0.193^{* *}$ & $1.299^{* * *}$ & $1.098^{* * *}$ & & $1.001^{* * *}$ \\
Reward Types & & & & $0.552^{* * *}$ & $0.272^{* * *}$ \\
Perceived Fit & & 0.463 & 0.320 & 0.339 & 0.513 \\
$\mathrm{R}^{2}$ & 0.039 & 0.455 & 0.309 & 0.329 & 0.503 \\
Adj.R & 0.029 & $56.592^{* * *}$ & $30.835^{* * *}$ & $33.665^{* * *}$ & $51.633^{* * *}$ \\
F & $4.011^{*}$ & & & &
\end{tabular}

Meanwhile, in order to improve the robustness of mediating effect, this study also used bootstrapping to verify the mediating effect. The Bootstrap sample size was set at 5000 and the confidence interval was set at $95 \%$. The results show that the total effect of the reward type on the referral likelihood for green products is significant $(\beta=1.299$, $\mathrm{SE}=0.106,95 \%$ BootCI $=[1.090,1.509])$, and the indirect effect of the reward type on the referral likelihood for green products is significant $(\beta=0.298, \mathrm{SE}=0.071,95 \% \mathrm{BootCI}=$ $[0.172,0.450])$, after controlling the perceived fit, the direct effect of the reward type on the referral likelihood for green products is still significant $(\beta=1.001, \mathrm{SE}=0.113,95 \% \mathrm{BootCI}=$ $[0.780,1.220])$. Again, the partial mediation role of perceived fit is verified, supporting H2. 


\subsection{Moderating Effect}

We used a three-step method to examine the moderating effect of green product knowledge [66]. In the first step, in order to eliminate the unequal contribution of variables and reduce multicollinearity, we standardized the continuous variables, and then created an interaction term between the independent variable and moderation variable. In the second step, the dependent variable (the perceived fit), control variable, independent variable and moderator variable were put into the regression equation in turn. In the third step, the interaction term was put into the regression equation.

According to the above analysis steps, we analyzed the moderating effect of green product knowledge. As seen in Table 4 , the green product knowledge positively moderates the relationship between the reward type and customers' perceived fit $(\beta=0.232, p=0.035)$. Thus, H3 is supported. That is, compared with the situation where customers have a low level of green product knowledge, the impact of reward types on their perceived fit will be enhanced when they have a high level of knowledge about green products. More specifically, for every increase of one standard deviation of the customers' green product knowledge, the standardized regression coefficient of the reward type to customers' perceived fit will increase by 0.232 .

Table 4. Analysis of moderating effect.

\begin{tabular}{cccccc}
\hline \multirow{2}{*}{ Variable } & \multicolumn{2}{c}{$\begin{array}{c}\text { Unstandardized } \\
\text { Coefficients }\end{array}$} & $\begin{array}{c}\text { Standardized } \\
\text { Coefficients }\end{array}$ & $\mathbf{t}$ & $p$ \\
\cline { 2 - 4 } & $\boldsymbol{B}$ & Std. Error & Standardized $\boldsymbol{B}$ & & \\
\hline Constant & -2.013 & 0.244 & & -8.262 & 0.000 \\
Gender & 0.186 & 0.113 & 0.092 & 1.650 & 0.101 \\
Product Involvement & 0.002 & 0.056 & 0.002 & 0.033 & 0.974 \\
GPK & 0.226 & 0.073 & 0.226 & 3.103 & 0.002 \\
Reward Type & 1.154 & 0.108 & 0.579 & 10.703 & 0.000 \\
GPK $\times$ Reward Type & 0.232 & 0.109 & 0.152 & 2.121 & 0.035 \\
\hline Note: 1 . Dependent variable $=$ Perceived fit; 2 . GPK $=$ Green product knowledge.
\end{tabular}

In order to better understand the moderating effect, we need to plot it. First, the mean of green product knowledge was calculated. Second, we created high and low levels based on above and below one standard deviation from mean of green product knowledge. Third, we drew the relationships between constructs $[67,68]$. Figure 3 exhibits the moderating effect of green product knowledge.

In addition, as Figure 3 shows customers with a higher level of green product knowledge perceive a higher fit between monetary rewards and green products than those with a lower level of knowledge of green products. The possible explanation for this result is as follows. Customers who have a higher level of green product knowledge usually pay more attention to environmental protection. Faced with monetary rewards, they will consider that this approach adopted by enterprises will help the promotion of green products and have a positive impact on the environment, which leads them to treat the monetary rewards with a more tolerant attitude and to hold that implementing monetary rewards for green products is not particularly inappropriate, thus, enhancing their perception of the fit between monetary rewards and green products. On the contrary, as for customers with a lower level of green products knowledge, they might take less consideration of the positive impact of monetary referral rewards on environmental protection and attribute the company's behavior to its purpose of increasing profits, which will result in their stricter way to treat monetary rewards. Hence, they will perceive more inconsistent between monetary rewards and green products, that is, relatively low fit. 


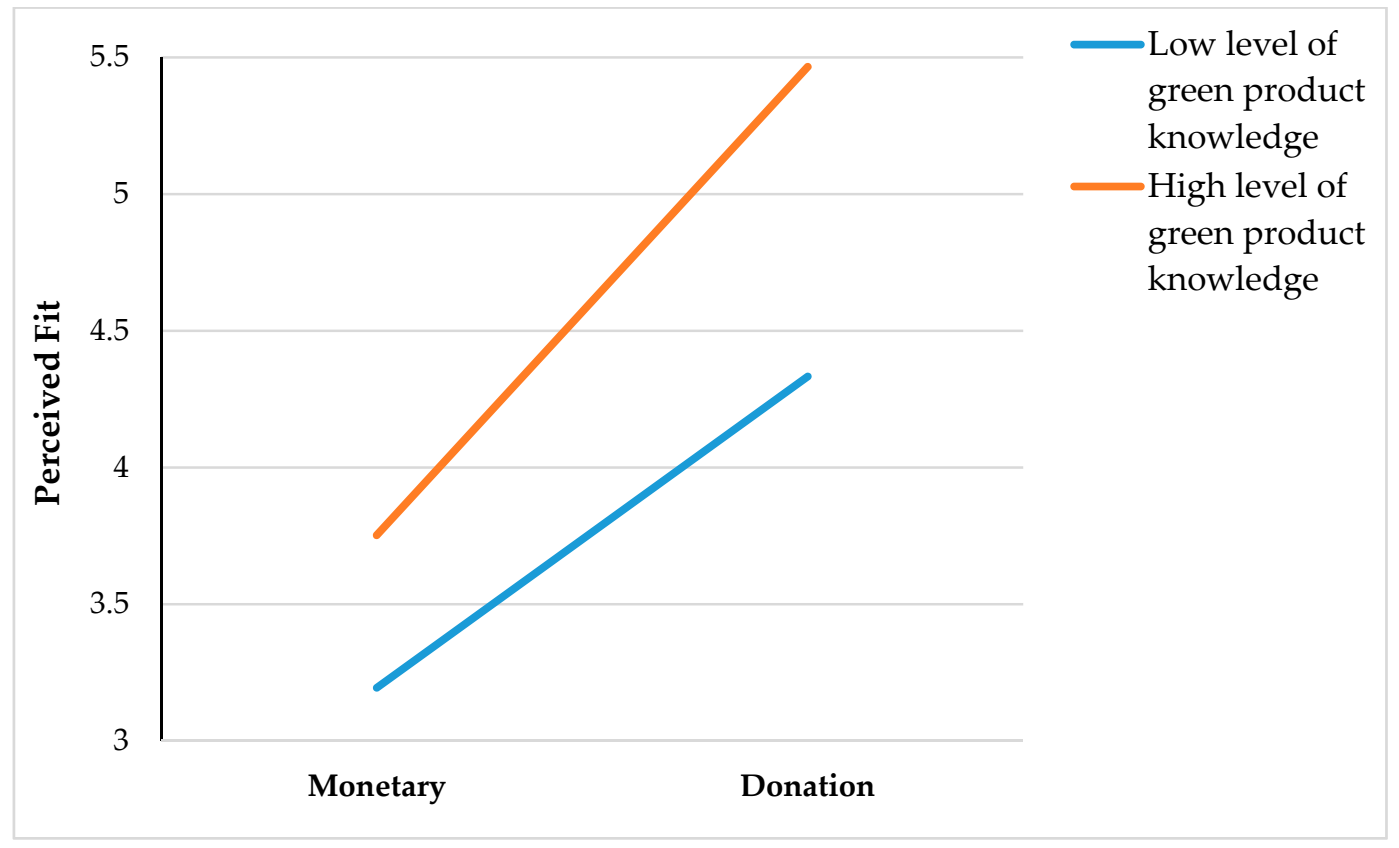

Figure 3. The moderating effect of green product knowledge on reward type and customers' perceived fit.

\section{Discussion}

\subsection{Conclusions}

As an effective marketing method to promote existing customers to recommend products to potential customers, the RRP has not received enough attention from researchers in the field of green marketing. Therefore, this article introduces the RRP into green products marketing. Based on the perspective of existing customers (i.e., recommenders), this research investigates the impacts of the reward types on existing customers' referral likelihood for green products and analyzes the process of this impact and the conditions under which the influence of the reward type will be enhanced.

As mentioned above, in the field of general products marketing, monetary rewards are more widely used and considered equally or more attractive than other types of rewards [69]. However, this study finds that the above conclusions are not applicable to the green products. The research shows that donation rewards are more effective than monetary rewards in promoting existing customers' referral likelihood for green products. This result can be explained based on the referrers' perception process. Specifically, compared with monetary rewards, donation rewards and green products have a perceptual fit of higher level, which contributes to improving existing customers' cognitive consistency between the reward and green products, then leads to their higher referral likelihood for the green product. In other words, the perceived fit plays a mediating role in the relationship between the reward types and the referral likelihood. Through the above analyses, it can be found that the customers do not always seek to maximize economic value. On the contrary, in the context of green products, the perceived fit between green products and rewards plays a more important role in the process of rewards influencing their recommendation behavior. However, most previous studies on the RRPs did not pay attention to the perceived fit between the reward and the product, especially for the RRPs designed for green products $[10,11]$.

In addition, knowledge can influence consumers' perception and preference [16]. In this research, we find that green product knowledge positively moderates the relationship between the reward types and the perceived fit. The higher level of green product knowledge a consumer is qualified with, the higher fit he or she would perceive between the donation reward and green products. Existing research on green product knowledge mainly investigate its positive effect on customers' purchase intentions for green prod- 
ucts [70,71]. For example, Wang et al. [51] reveal that green product knowledge positively impacts perceived consumer effectiveness, then increase consumers' green purchase intention. This research that is based on the context of green product referral finds that green product knowledge will enhance the impact of reward types on the perceived fit. In this case, it can be concluded that improving customers' knowledge of green products will not only help promote them to purchase green products, but also help improve their perception of the fit between donation rewards and green products, thereby improving their referral likelihood for green products.

\subsection{Theoretical Contributions}

This research contributes to the existing literature in the following ways. First, this research focuses on the referral behavior of green products and extends the literature on green marketing by introducing the RRP. Previous research on green marketing mainly focuses on the purchase of green products, analyzing the demographic characteristics of customers who buy green products, the factors that influence customers to purchase green products, and some traditional marketing methods that promote customers to buy green products, such as advertising [1,3,72], promotion [73,74], etc. However, few studies have paid attention to the recommendation for green products, despite the fact that interpersonal recommendations can effectively reduce customers' perceived risk and promote their purchasing intentions. Therefore, it is important to explore how to encourage existing customers to recommend green products. To this end, this article introduces the RRP into green marketing and analyzes its role in improving the existing customers' referral likelihood for green products, providing a new perspective for the promotion of green products.

Second, this study expands the product type that RRPs applicable to. Existing research on RRPs mainly focuses on ordinary products, but leaves green products ignored. However, green products, which play a crucial rule in saving resources and protecting the environment, are significantly different from ordinary products. Therefore, it is necessary to conduct relevant research specifically for green products. This research is perhaps the first one to study how to design and implement the RRP for green products.

Third, this study contributes to an extensive understanding of the impact of perceived fit. We reveal the internal mechanism underlying the impact of reward types on customers' referral likelihood for green products and illustrate that compared with monetary rewards, the perceived fit between the donation reward and the green product is higher, which, in turn, leads to a greater referral likelihood. The findings of the impact of perceived fit in the context of RRP designed for green products are consistent with the conclusions in the fields of brand development [36,37], sponsorship [42] and celebrity endorsement [43-45], providing further evidence for the positive effect of fit.

Finally, this article expands the research on green product knowledge from the context of green purchase to the context of green product recommendation. Existing research on green product knowledge is mainly based on the context of green purchase to study its direct or moderating effects $[51,70,71]$. In this research, we extend it to the recommendation context and find that green product knowledge would positively moderate the relationship between reward type and perceived fit.

\subsection{Managerial Implications}

First, companies should implement the RRP for green products. Interpersonal recommendation can effectively increase customers' purchase intentions, and the implementation of the RRP can significantly enhance the possibility of existing customers' recommendation for green products, regardless of the reward type. For this reason, existing environmental protection companies should pay attention to the RRP and invest corresponding marketing resources to the RRP to improve existing customers' referral likelihood as much as possible.

Second, when the reward cost is constant, companies should implement donation rewards more. For green products, donation rewards are better than monetary rewards 
in enhancing the possibility of customer recommendation. For this reason, managers should invest more energy and marketing resources on donation rewards. For example, companies could increase their attention and devotion to existing charitable donations, or they can take the initiative to contact some local governments or organizations that have not yet carried out charitable donations but do need assistance. This will not only help the companies implement the RRP more effectively, but also will help them better fulfillment social responsibilities and improve their reputation.

Third, government and relevant non-governmental organizations (NGO), schools, and companies should work together to promote the dissemination and sharing of green product knowledge. The higher level of knowledge about green products existing customers have, the higher the perceived fit between donation rewards and green products. Green product knowledge is representative of social concern and would help to reinforce the idea of the social construct at work in the fit of a social benefit producing positive affect (referral). More importantly, donation rewards can not only help to improve the effect of the RRP, but also contribute to the improvement of the well-being of the entire society. Therefore, to maximize the positive effect of donation rewards, government and relevant NGO, schools, and companies should work together to increase customers' green product knowledge. Specifically, government departments and NGO related to environmental protection should strengthen the promotion and training of green product knowledge, such as increasing the shooting and broadcasting of public service advertisements related to environmental protection and green consumption, and calling for companies to train their employees on green product knowledge, etc. At the same time, schools should also take actions to spread green product knowledge, trying to provide students with accesses to visit and learn from environmental protection companies. As for companies, firstly, they should highlight the green attributes of products in the design of packaging, advertising and RRPs; secondly, sales staff should consciously impart relevant green product knowledge to customers while promoting green products; thirdly, companies should also make good use of social media. They can invite key opinion leaders to publish topics about green product knowledge on social media to encourage customers to participate in the discussion actively, thereby improving customers' green product knowledge.

\subsection{Limitations and Future Research Directions}

Although this study has drawn some useful conclusions, there are still several limitations. First, this research investigates the moderating role of green product knowledge in the relationship between the reward type and customers' perceived fit, however, there might be other moderation variables such as existing customers' thinking type (analytic or holistic), cognitive ability, and transaction tendency, etc., which can be further explored in the future. Second, this study was conducted in China. Although there are no constructs of country and cultural background in the research framework, and the promotion and consumption of green products are the common topics in the world, it may be more rigorous to further verify the conclusions of this study to other countries in the future. Third, this study was conducted based on the environmentally friendly backpack industry. Future research can replicate this research to other green product industries. Finally, this research adopts the method of scenario experiments to reveal the relationship between variables. Although the scenario has been set to imitate the real scene as much as possible, there are still some differences between the experiment scenario and the actual scene. For future research, longitudinal research methods and enterprise or industry data can be used to improve the external validity of the research results.

Author Contributions: Conceptualization, D.K., X.-F.L. and W.-W.B.; Formal analysis, D.K.; Investigation, D.K.; Methodology, D.K.; Supervision, X.-F.L.; Validation, W.-W.B.; Writing—original draft, D.K.; Writing - review \& editing, X.-F.L. All authors have read and agreed to the published version of the manuscript. 
Funding: This study was supported by the National Natural Science Foundation of China (Grant No. 71672008), Beijing Natural Science Foundation (Grant No. 9162012), and China Postdoctoral Science Foundation (Grant No. 2020M670170).

Institutional Review Board Statement: The study was conducted according to the guidelines of the Declaration of Helsinki, and approved by the Institutional Review Board of Beijing Institute of Technology (protocol code 52, 25 November 2010).

Informed Consent Statement: Informed consent was obtained from all subjects involved in the study.

Data Availability Statement: The data are not publicly available to protect the confidentiality of the participants.

Acknowledgments: Firstly, we would like to express our gratitude to Hong Wang for his valuable suggestions and Ru-Bing Bai for her language improvement support. Secondly, we are grateful to assistant editor Irena Radulović for processing our manuscript. Thirdly, we sincerely thank three reviewers for putting forward many constructive comments to our manuscript. Finally, we thank the participating respondents for their time and effort.

Conflicts of Interest: The authors declare no conflict of interest.

\section{References}

1. Sun, Y.; Luo, B.; Wang, S.; Fang, W. What you see is meaningful: Does green advertising change the intentions of consumers to purchase eco-labeled products? Bus. Strategy Environ. 2021, 30, 694-704. [CrossRef]

2. Wang, J.; Wang, S.; Xue, H.; Wang, Y.; Li, J. Green image and consumers' word-of-mouth intention in the green hotel industry: The moderating effect of Millennials. J. Clean. Prod. 2018, 181, 426-436. [CrossRef]

3. Yuan, Y.-N.; Song, T.; Wu, S.-L. Study on the effects of green advertising appeal on purchase intention: The mediating role of green purchase affection and the moderating role of self-construal. Forecasting 2020, 39, 81-88.

4. Chen, Y.S.; Chang, C.H. Enhance green purchase intentions: The roles of green perceived value, green perceived risk, and green trust. Manag. Decis. 2012, 50, 502-520. [CrossRef]

5. Villanueva, J.; Yoo, S.; Hanssens, D.M. The impact of marketing-induced versus word-of-mouth customer acquisition on customer equity growth. J. Mark. Res. 2008, 45, 48-59. [CrossRef]

6. Ramaseshan, B.; Wirtz, J.; Georgi, D. The enhanced loyalty drivers of customers acquired through referral reward programs. J. Serv. Manag. 2017, 28, 687-706. [CrossRef]

7. Van den Bulte, C.; Bayer, E.; Skiera, B.; Schmitt, P. How customer referral programs turn social capital into economic capital. J. Mark. Res. 2018, 55, 132-146. [CrossRef]

8. Berman, B. Referral marketing: Harnessing the power of your customers. Bus. Horiz. 2015, 59, 19-28. [CrossRef]

9. Schmitt, P.; Skiera, B.; Van, D.B.C. Referral programs and customer value. J. Mark. 2011, 75, 46-59. [CrossRef]

10. Verlegh, P.W.J.; Ryu, G.; Tuk, M.A.; Feick, L. Receiver responses to rewarded referrals: The motive inferences framework. J. Acad. Mark. Sci. 2013, 41, 669-682. [CrossRef]

11. Jin, L.; Huang, Y. When giving money does not work: The differential effects of monetary versus in-kind rewards in referral reward programs. Int. J. Res. Mark. 2014, 31, 107-116. [CrossRef]

12. Yu, C.L.; Zhu, X.D.; Wang, X.; Zhang, Y.F. Face consciousness and green buying intention: The moderating effect of consumption context and mediating effect of price. Manag. Rev. 2019, 31, 139-146.

13. Czellar, S. Consumer attitude toward brand extensions: An integrative model and research propositions. Int. J. Res. Mark. 2003, 20, 97-115. [CrossRef]

14. Stumpf, C.; Baum, M. Customer referral reward-brand-fit: A schema congruity perspective. Psychol. Mark. 2016, 33, 542-558. [CrossRef]

15. Clemente, S.; Dolansky, E.; Mantonakis, A.; White, K. The effects of perceived product-extrinsic cue incongruity on consumption experiences: The case of celebrity sponsorship. Mark. Lett. 2014, 25, 373-384. [CrossRef]

16. Tan, B.C. The roles of knowledge, threat, and PCE on green purchase behaviour. Int. J. Bus. Manag. 2011, 6, 14-27. [CrossRef]

17. Liu, C.Y.; Lv, H.Y. Green management: The inevitable trend of the sustainable development of modern enterprises. Modern Enterprises 2002, 6, 12-13.

18. Yang, X.Y.; Zhou, Y.J. Green value: A new dimension of customer perceived values. China Ind. Econ. $2006,7,110-116$.

19. Wu, B. A review of green consumption research. Econ. Manag. 2014, 36, 178-189.

20. Brough, A.R.; Wilkie, J.E.; Ma, J.; Isaac, M.S.; Gal, D. Is eco-friendly unmanly? The green-feminine stereotype and its effect on sustainable consumption. J. Consum. Res. 2016, 43, 567-582. [CrossRef]

21. Zhao, H.H.; Gao, Q.; Wu, Y.P.; Yuan, W.; Zhu, X.D. What affects green consumer behavior in china? A case study from qingdao. J. Clean. Prod. 2014, 63, 143-151. [CrossRef]

22. Bai, G.L.; Wan, C.Y. Investigation on the status quo and influencing factors of urban residents' green consumption. Consum. Econ. 2012, 28, 92-94. 
23. Granzin, K.L.; Olsen, J.E. Characterizing participants in activities protecting the environment: A focus on donating, recycling, and conservation behaviors. J. Public Policy Mark. 1991, 10, 1-27. [CrossRef]

24. Wang, G.M.; Li, J.X.; Liao, S.X.; Wen, L. Environmental values and consumers' green purchasing behavior-a study on the mediating effect of environmental attitudes. J. Dalian Univ. Technol. 2010, 31, 37-42.

25. Mamun, A.A.; Mohamad, M.R.; Mohamad, R.B.Y.; Muhammad, M. Intention and behavior towards green consumption among low-income households. J. Environ. Manag. 2018, 227, 73-86. [CrossRef]

26. $\mathrm{Wu}, \mathrm{B}$; Y Yang, Z. The impact of moral identity on consumers' green consumption tendency: The role of perceived responsibility for environmental damage. J. Environ. Psychol. 2018, 59, 74-84. [CrossRef]

27. Wang, H.; Ma, B.L.; Bai, R.B. The spillover effect of greenwashing behaviours: An experimental approach. Mark. Intell. Plan. 2020, 38, 283-295. [CrossRef]

28. Romaniuk, J.; Hartnett, N. The relative influence of advertising and word-of-mouth on viewing new season television programmes. Eur. J. Market. 2017, 51, 65-81. [CrossRef]

29. Zhang, D.P.; Zhang, F.L.; Liu, S.; Du, H.S. Impact of referral reward program on innovative customers' follow-up e-referral. Inf. Technol. People. 2019, 32, 559-578. [CrossRef]

30. Garnefeld, I.; Eggert, A.; Helm, S.V.; Tax, S.S. Growing existing customers' revenue streams through customer referral program. J. Mark. 2013, 77, 17-32. [CrossRef]

31. Zhu, Y.M. Hedonic or utilitarian: The impact of product type and reward type on consumers referral likelihood. J. Mark. Sci. 2014, 10, 15-28. [CrossRef]

32. Arora, N.; Henderson, T. Embedded premium promotion: Why it works and how to make it more effective. Mark. Sci. 2007, 26, 514-531. [CrossRef]

33. Song, C.; Wang, T.; Hu, M.Y. Referral reward programs with scarcity messages on bank credit card adoption. Int. J. Bank. Mark. 2019, 37, 531-544. [CrossRef]

34. Yu, C.L.; Wang, X.; Bao, H.H. Referral reward programs: The influence of word of mouth on recipients' attitude and purchase intention. Nankai. Bus. Rev. 2011, 14, 59-68.

35. Wirtz, J.; Chew, P. The effects of incentives, deal proneness, satisfaction and tie strength on word-of-mouth behaviour. Int. J. Ser. Industry Manag. 2012, 13, 141-162. [CrossRef]

36. Aaker, D.A.; Keller, K.L. Consumer evaluations of brand extensions. J. Mark. 1990, 54, 27-41. [CrossRef]

37. Boush, D.M.; Loken, B. A process-tracing study of brand extension evaluation. J. Mark. Res. 1991, 28, 16-28. [CrossRef]

38. Völckner, F.; Sattler, H. Drivers of brand extension success. J. Mark. 2006, 70, 18-34. [CrossRef]

39. Simonin, B.L.; Ruth, J.A. Is a company known by the company it keeps? Assessing the spillover effects of brand alliances on consumer brand attitudes. J. Mark. Res. 1998, 35, 30-42. [CrossRef]

40. Keller, K.L.; Aaker, D.A. The effects of sequential introduction of brand extensions. J. Mark. Res. 1992, 29, 35-50. [CrossRef]

41. Speed, R.; Thompson, P. Determinants of sports sponsorship response. J. Acad. Mark. Sci. 2000, 28, 226-238. [CrossRef]

42. Mazodier, M.; Merunka, D. Achieving brand loyalty through sponsorship: The role of fit and self-congruity. J. Acad. Mark. Sci. 2011, 40, 807-820. [CrossRef]

43. Kamins, M.A. An investigation into the "match-up" hypothesis in celebrity advertising: When beauty may be only skin deep. $J$. Advert. 1990, 19, 4-13. [CrossRef]

44. Till, B.D.; Busler, M. The match-up hypothesis: Physical attractiveness, expertise, and the role of fit on brand attitude, purchase intent and brand beliefs. J. Advert. 2000, 29, 1-13. [CrossRef]

45. Till, B.D.; Stanley, S.M.; Priluck, R. Classical conditioning and celebrity endorsers: An examination of belongingness and resistance to extinction. Psychol. Mark. 2008, 25, 179-196. [CrossRef]

46. Mitchell, D.J.; Barbara, E.K.; Susan, C.K. There's something in the air: Effects of congruent or incongruent ambient odor on consumer decision making. J. Consum. Res. 1995, 22, 229-238. [CrossRef]

47. Lafferty, B.A. The relevance of fit in a cause-brand alliance when consumers evaluate corporate credibility. J. Bus. Res. 2007, 60, 447-453. [CrossRef]

48. Festinger, L. A Theory of Cognitive Dissonance; Stanford University Press: Stanford, CA, USA, 1975.

49. Klink, R.R.; Smith, D.C. Threats to the external validity of brand extension research. J. Mark. Res. 2001, 38, 326-335. [CrossRef]

50. Rosch, E.H.; Mervis, C.B. Family resemblances: Studies in the internal structure of categories. Cogn. Psychol. 1975, 7, 573-605. [CrossRef]

51. Wang, H.; Ma, B.L.; Bai, R.B. How does green product knowledge effectively promote green purchase intention? Sustainability 2019, 11, 1193. [CrossRef]

52. Berinsky, A.J.; Huber, G.A.; Lenz, G.S. Evaluating online labor markets for experimental research: Amazon.com's mechanical turk. Political Anal. 2012, 20, 351-368. [CrossRef]

53. Wirtz, J.; Orsingher, C.; Chew, P.; Tambyah, S.K. The role of metaperception on the effectiveness of referral reward programs. J. Serv. Res. 2013, 16, 82-98. [CrossRef]

54. Bateson, J.E.G.; Hui, M.K. The ecological validity of photographic slides and videotapes in simulating the service setting. J. Consum. Res. 1992, 19, 271-281. [CrossRef]

55. Wirtz, J.; Bateson, J.E.G. Consumer satisfaction with services: Integrating the environment perspective in services marketing into the traditional disconfirmation paradigm. J. Bus. Res. 1999, 44, 55-66. [CrossRef] 
56. Ryu, G.; Feick, L. A penny for your thoughts: Referral reward programs and referral likelihood. J. Mark. 2007, 71, 84-94. [CrossRef]

57. Dose, D.B.; Walsh, G.; Beatty, S.E.; Elsner, R. Unintended reward costs: The effectiveness of customer referral reward programs for innovative products and services. J. Acad. Mark. Sci. 2019, 47, 438-459. [CrossRef]

58. Viswanathan, V.; Tillmanns, S.; Krafft, M.; Asselmann, D. Understanding the quality-quantity conundrum of customer referral programs: Effects of contribution margin, extraversion, and opinion leadership. J. Acad. Mark. Sci. 2018, 46, 1108-1132. [CrossRef]

59. Mittal, B. Comparative analysis of four scales of consumer involvement. Psychol. Mark. 1995, 12, 663-682. [CrossRef]

60. Sundaram, D.S.; Mitra, K.; Webster, C. Word-of-mouth communications: A motivational analysis. Adv. Consum. Res. 1998, 25, 527-531.

61. Mr.ace Homme Brand Backpack Made of Environmentally Friendly Technical Fabrics. Available online: https://item.jd.com/56 371764779.html (accessed on 11 October 2019).

62. Wang, Q.; Sun, Y.; Zhang, X.H. The Effects of Product-Gift Fit on the Uncertainty Gift Promotion. J. Manag. Sci. 2018, 31, 120-130.

63. Liobikienè, G.; Mandravickaitè, J.; Bernatonienè, J. Theory of planned behavior approach to understand the green purchasing behavior in the EU: A cross-cultural study. Ecol. Econ. 2016, 125, 38-46. [CrossRef]

64. Beatty, S.E.; Talpade, S. Adolescent influence in family decision making: A replication with extension. J. Consum. Res. 1994, 21, 332-334. [CrossRef]

65. Hair, J.F.; Black, W.C.; Babin, B.J.; Anderson, R.E. Multivariate Data Analysis; Prentice Hall: Upper Saddle River, NJ, USA, 2010.

66. Wen, Z.L.; Hou, J.T.; Zhang, L. A comparison of moderator and mediator and their implications. Acta. Psychol. Sin. 2005, 37, 268-274.

67. Li, J.; Tang, Y.I. CEO hubris and firm risk taking in China: The moderating role of managerial discretion. Acad. Manag. 2010, 53, 45-68. [CrossRef]

68. Dawson, J.F. Moderation in management research: What, why, when, and how. J. Bus. Psychol. 2014, 29, 1-19. [CrossRef]

69. Biyalogorsky, E.; Gerstner, E.; Libai, B. Customer referral management: Optimal reward programs. Mark. Sci. 2001, 20, 82-95. [CrossRef]

70. Kang, J.; Liu, C.; Kim, S.H. Environmentally sustainable textile and apparel consumption: The role of consumer knowledge, perceived consumer effectiveness and perceived personal relevance. Int. J. Consum. Stud. 2013, 37, 442-452. [CrossRef]

71. Mostafa, M.M. Gender differences in Egyptian consumers' green purchase behaviour: The effects of environmental knowledge, concern and attitude. Int. J. Consum. Stud. 2007, 31, 220-229. [CrossRef]

72. Sheehan, K.; Atkinson, L. Revisiting green advertising and the reluctant consumer. J. Advert. 2012, 41, 5-7. [CrossRef]

73. Zou, J.; Tang, Y.; Qing, P.; Li, H.; Razzaq, A. Donation or discount: Effect of promotion mode on green consumption behavior. Int. J. Environ. Res. Public Health 2021, 18, 1912. [CrossRef]

74. Sheng, G.H.; Gong, S.Y.; Yue, B.B.; Ou, Y.L. The influence mechanism of the promotional information framework on green buying behaviors-based on the moderating effect of non-green alternative attractiveness. J. Dalian Univ. Technol. 2020, 41, 38-47. 